\title{
Hubungan Kemampuan Keluarga Dalam Mengenal Masalah Dengan Upaya Keluarga Mencegah Kekambuhan Demam Berdarah Dengue (Dbd) Di Pagesangan Timur Wilayah Kerja Puskesmas Pagesangan
}

\author{
Mardian Andriani \\ ${ }^{1}$ STKIP Taman Siswa Bima \\ 1mardianandriani280308@gmail.com
}

\begin{abstract}
Abstrak. Angka kejadian Demam Berdarah Dengue (DBD) tertinggi berada di Puskesmas Pagesangan dengan 89 kasus pada tahun 2007, dengan rincian Kelurahan Pagesangan 40 kasus, Kelurahan Mataram Timur 33 kasus dan Kelurahan Dasan Agung sebanyak 16 kasus. Sementara data per Januari-Desember 2008 terdata sebanyak 30 kasus di Kelurahan Pagesangan. Pada tahun 2008-2009 tercatat 63 kasus (49,22\%) Demam Berdarah Dengue (DBD) di Kelurahan Pagesangan Timur. Hasil Survey di Kelurahan Pagesangan Timur menunjukkan bahwa terdapat banyak genanan air dan jentik nyamuk, sampah plastik, halaman rumah yang terlalu rindang dan pencahayaan matahari yang kurang. Penelitian ini menggunakan desain studi korelasional dengan pendekatan cross sectional. Pengambilan sampel dilakukan dengan teknik total sampling sebanyak 36 KK. Analisis data menggunakan Rank Spearman dengan nilai alfa 0.05. Hasil penelitian diperoleh nilai $r$ sebesar 0,341 dengan sig (2-tailled) sebesar 0,042. Berdasarkan hasil interpretasi nilai $r$ dapat dikatakan bahwa ada hubungan dengan nilai korealasi yang rendah antara kemampuan keluarga mengenal masalah dengan upaya keluarga mencegah kekambuhan Demam Berdarah Dengue (DBD), artinya masih ada faktor lain yang memiliki hubungan yang lebih kuat terhadap kejadian Demam Berdarah Dengue (DBD) yang tidak terangkum dalam penelitian ini. Diharapkan keluarga untuk lebih meningkatkan upaya-upaya untuk pencegahan Demam Berdarah Dengue (DBD) di dalam maupun di luar rumah sehingga resiko terjangkit maupun serangan berulang Demam Berdarah Dengue (DBD) dapat di turunkan.
\end{abstract}

\section{Kata Kunci: Senam Osteoporosis, Nyeri Muskuloskeletal, Lansia}

\section{PENDAHULUAN}

Demam Berdarah Dengue (DBD) merupakan masalah kesehatan di Indonesia yang sering menyebabkan kejadian luar biasa (KLB) dengan angka kematian yang tinggi. Penyakit ini disebabkan oleh gigitan nyamuk Aedes Aegypti dengan ciri demam tinggi mendadak yang disertai perdarahan yang beresiko menimbulkan shock dan kematian. Vekto utama dari penyakit Demam Berdarah Dengue (DBD) adalah lingkungan, sehingga upapay untuk memelihara dan meningkatkan derajat kesehatan masyarakat dengan memperhatikan faktor lingkungan sebagai vektor utama (Wahyuni, 2008).

Angka kejadian Demam Berdarah Dengue (DBD) tertinggi berada di Puskesmas Pagesangan dengan 89 kasus pada tahun 2007, dengan rincian Kelurahan Pagesangan 40 kasus, Kelurahan Mataram Timur 33 kasus dan Kelurahan Dasan Agung sebanyak 16 kasus.
Sementara data per Januari-Desember 2008 terdata sebanyak 30 kasus di Kelurahan Pagesangan. Pada tahun 2008-2009 tercatat 63 kasus $(49,22 \%)$ Demam Berdarah Dengue (DBD) di Kelurahan Pagesangan Timur. Hasil Survey di Kelurahan Pagesangan Timur menunjukkan bahwa terdapat banyak genanan air dan jentik nyamuk, sampah plastik, halaman rumah yang terlalu rindang dan pencahayaan matahari yang kurang.

Data dinas kesehatan Kota Mataram per Mei 2009, mencatat sebanyak 380 kasus Demam Berdarah Dengue (DBD), sementara di tahun sebelumnya tercatat sebanyak 225 kasus dan tidak ada yang meninggal dunia (Ady, 2009). Hasil wawancara dengan beberapa keluarga diperoleh data bahwa kondisi lingkungan memang sudah kotor seperti dan semakin parah saat musim hujan tiba terutama meningkatkan daerah yang tergenang air dan sampah yang berserakan. Keluarga juga 
menyampaikan bahwa mereka belum mampu membedakan demam akibat penyakit Demam Berdarah Dengue (DBD) dengan demam lainnya. Keluarga juga belum mampu membedakan mana nyamuk Aedes Aegypti penyebab Demam Berdarah Dengue (DBD) dengan nyamuk lainnya. Meskipun di Lingkungan Pagesangan Timur sudah sering melakukan gotong royong lingkungan belum mampu menurunkan angka kejadian Demam Berdarah Dengue (DBD).

Berdasarkan rumusan masalah penelitian yang diteliti dapat disimpulkan bahwa tujuan penelitian adalah : 1) Mengidentifikasi kemampuan keluarga dalam mengenal masalah kesehatan keluarga di Kelurahan Pagesangan Timur; 2) Mengidentifikasi upaya keluarga mencegah kekambuhan Demam Berdarah Dengue (DBD) di Kelurahan Pagesangan Timur; 3) Menganalisa hubungan kemampuan keluarga dalam mengenal masalah dengan upaya mencegah kekambuhan Demam Berdarah Dengue (DBD) di Kelurahan Pagesangan Timur Wilayah Kerja Puskesmas Pagesangan.

\section{Keluarga}

Menurut Friedman (1998) dalam Suprajitno (2004) menjelaskan bahwa keluarga merupakan sekumpulan dua atau lebih orang yang hidup bersama yang terikat dengan aturan, emosional dengan perannya masing-masing. Sementara menurut DepKes RI menjelaskan bahwa keluarga merupakan kelompok terkecil yang ada di masyarakat yang terdiri dari kepala dan beberapa anggota keluarga yang hidup bersama dan saling bergantung satu sama lain.

Tugas keluarga dalam mengatasi masalah kesehatan dalam Suprajitno (2004) adalah :

1. Mengenal masalah kesehatan keluarga yang meliputi pengertian Demam Berdarah Dengue (DBD), tanda dan gejala dari Demam Berdarah Dengue (DBD), penyebab Demam Berdarah Dengue (DBD), perbedaan nyamuk Demam Berdarah Dengue (DBD) dengan nyamuk lainnya, dampak dari penyakit Demam Berdarah Dengue (DBD).

2. Memutuskan tindakan kesehatan yang tepat bagi keluarga berupaya usaha untuk mencari pertolongan di pusat pelayanan kesehatan terdekat atau tenaga kesehatan yang ada.
3. Merawat keluarga yang mengalami gangguan kesehatan.

4. Memodifikasi lingkungan keluarga untuk menjamin kesehatan keluarga yang meliputi penyediaan tempat sampah, membuang sampah pada tempatnya, menguras bak mandia atau penampungan air $1 \mathrm{X}$ seminggu, mengganti atau menguras vas bunga dan tempat minum burung seminggu sekali, menutup rapat tempat penampungan air, mengubur kaleng bekas, botol, ban dan sampah lainnya yang ada disekitar lingkungan, menggunakan kelambu atau kipas angin, singkirkan pakaian yang ada dalam kamar tidur yang bergantungan, menggunakan lotion anti nyamuk, menggunakan pakaian yang panjang.

5. Manfaatkan fasilitas pelayanan kesehatan disekitarnya bagi keluarga.

Faktor-faktor yang mempengaruhi 5 tugas keluarga yaitu:

1. Pendidikan

2. Jenis pekerjaan

3. Pendapatan keluarga

Pengetahuan

Menurut Notoadmodjo (2002), pengetahuan adalah hasil tahu setelah seseorang melakukan penginderaan terhadap objek tertentu, melalui panca indera yaitu indera peraba, pendengaran, penciuman, rasa dan penglihatan dan paling seringnya melalui indera penglihatan dan pendengaran. Pengetahuan merupakan teori dan fakta yang memungkinkan seseorang mampu memecahkan masalah. Pengetahuan dapat diperoleh melalui pengalaman yang diperoleh baik secara langsung maupun secara tidak langsung.

Tingkatan dalam pengetahuan yaitu, 1) tahu; 2) memahami; 3) aplikasi; 4) analisis; 5) sintesis; 6) evaluasi. Sementara faktor-faktor yang mempengaruhi pengatahuan adalah pendidikan, coba-salah, kekuasaan, pengalaman pribadi dan jalan pikiran (Notoadmodjo, 2002).

\section{Demam Berdarah Dengue (DBD)}

Demam Berdarah Dengue (DBD) adalah penyakit yang terdapat pada anak maupun orang dewasa dengan gejala klinis demam, nyeri otot atau sendi, leukopenia, dengan atau tanpa ruam dan linfadenopati, sakit kepala yang hebat, nyeri pada pergerakan bola mata, rasa mengecap yang terganggu, trombositipenia dan 
bintik perdarahan (Hendarwanto, 1996). Demam Berdarah Dengue (DBD) merupakan penyakit menular yang dapat menyebabkan wabah (WHO, 2004).

Penyebab Demam Berdarah Dengue (DBD) adalah virus Dengue yang dibawa oleh nyamuk aedes aegypti yang mempunyai ciri belang hitam putih diseluruh tubuh sebagai vektor ke tubuh manusia melalui gigitan nyamuk tersebut. Nyamuk ini hanya berkembang biak pada air bersih dan menggigit hanya pada pagi dan sore hari dengan kemampuan terbang sejauh 100 meter (Mansjoer, 2000). Demam Berdarah Dengue (DBD) dapat ditegakkan diagnosisnya melalui uji laboratorium berupa uji serologi, isolaso virus, deteksi antigen dan deteksi RNA/DNA. Pemeriksaan penunjangnya adalah pemeriksaan trombosit, jika hasil uji trombosit menunjukkan hasil < 100.000/mmdan terjadi peningkatan nilai hematokrit sebesar $>20 \%$ maka seseorang dapat didiagnosa Demam Berdarah Dengue (DBD).

Pencegahan penyakit Demam Berdarah Dengue (DBD) dapat dilakukan dengan pemutusan rantai penularan, pemberantasan vektor. Pemberantasan nyamuk penyebab Demam Berdarah Dengue (DBD) pada dasarnya sangat mudah karena jarak tempuh nyamuk yang terbatas, tetapi karena vektor yang tersebar luas sehingga untuk keberhasilan pemberantasan diperlukan total coverage agar nyamuk tidak dapat berkembang biak lagi. Tindakan yang dapat dilakukan oleh keluarga untuk mencegah penyebaran penyakit Demam Berdarah Dengue (DBD) adalah gerakan 3M plus yaitu menguras tempat-tempat penampungan air minimal seminggu sekali atau menaburinya dengan bubuk abate, membunuh jentik nyamuk dan menutup rapat tempat penampungan air serta mengubur atau mebuang sampah pada tempatnya. Upaya lain yang dapat dilakukan untuk mencegah gigitan nyamuk adalah menggunakan obat anti nyamuk, tidur dengan kelambu, menggunakan kipas angin, menggunakan pakaian tebal dan panjang (Kadun, 2004)

\section{METODE PENELITIAN}

Penelitian ini merupakan penelitian studi korelasional dengan pendekatan cross sectional.
Penelitian ini dilakukan di Kelurahan Pagesangan Timur Kota Mataram, dengan jumlah populasi sebanyak 36 KK. Pengambilan Sampel dilakukan dengan teknik total sampling dengan jumlah sampel sebanyak 36 KK. Pengumpulan data dilakukan dengan dua cara yaitu observasi dan wawancara. Observasi digunakan untuk memperoleh data tentang upaya keluarga dalam mencegah kekambuhan Demam Berdarah Dengue (DBD), sedangkan wawancara digunakan untuk memvalidasi data yang telah diobervasi. Data hasil penelitian yang telah dikumpulkan kemudian di olah dengan menggunakan spearman rank.

\section{HASIL DAN PEMBAHASAN}

Hasil penelitian diketahui bahwa keluarga dengan upaya keluarga mencegah kekambuhan Demam Berdarah Dengue (DBD) dengan kategori cukup sebanyak 27 KK (75\%) belum mampu melaksanakan upaya untuk mengubur atau membuang sampah botol/ban, plastik, kaleng dengan baik, belum mampu menjaga kebersihan dalam lingkungan rumah, ventilasi atau lubang angin tidak diberi kawat kasa. Sedangkan KK dengan kategori kurang dalam upaya pencegahan kekambuhan Demam Berdarah Dengue (DBD) sebanyak $1 \mathrm{KK}$ $(2,78 \%)$, rata-rata tidak menggunakan obat anti nyamuk dan ventilasi atau lubang angin tidak berikan kawat kasa. Berdasarkan hasil uji rank spearman diperoleh nilai $r$ hitung sebesar 0,341 dengan sig (2-tailled) sebesar 0,042. Berdasarkan hasil interpretasi nilai $r$ dapat dikatakan bahwa ada hubungan dengan nilai korealasi yang rendah antara kemampuan keluarga mengenal masalah dengan upaya keluarga mencegah kekambuhan Demam Berdarah Dengue (DBD), artinya masih ada faktor lain yang memiliki hubungan yang lebih kuat terhadap kejadian Demam Berdarah Dengue (DBD) yang tidak terangkum dalam penelitian ini.

Upaya pencegahan Demam Berdarah Dengue (DBD) harus didukung oleh pengetahuan yang baik tentang penyebab dan bagaiman proses terjangkitnya Demam Berdarah Dengue (DBD). Maironah (2005) menjelaskan bahwa pengetahuan merupakan salah satu dari beberapa faktor yang mempengaruhi sikap, perilaku dan tindakan 
yang akan diambil oleh keluarga, dimana perilaku keluarga untuk mencegah Demam Berdarah Dengue (DBD) merupakan keterlibatan dalam bentuk tanggung jawab mental dan emosional. Masih adanya keluarga yang belum mampu melaksanakan upaya pencegan Demam Berdarah Dengue (DBD) dengan maksimal karena keluarga terlalu sibuk dengan pekerjaannya di kantor dan sebagian besar keluarga enggan memangkas tanaman yang cukup rindang di sekitar halaman rumah sehingga cahaya matahari kurang. Friedman dalam Suprajitno (2004) menyampaikan bahwa terdapat tiga faktor yang mempengaruhi keluarga dalam melaksanakan tugas keluarga diantaranya pendidikan yang mempengaruhi pengetahuan, pekerjaan dan pendapatan keluarga. Jenis pekerjaan sendiri sangat berperan dalam menimbulkan masalah dalam keluarga.

Hasil wawancara dengan keluarga yang ada di Kelurahan Pagesangan Timur diperoleh data bahwa dalam satu keluarga ada yang menderita Demam Berdarah Dengue (DBD) lebih dari satu kali dengan jarak kekambuhan yang sangat dekat dan data ini juga sesuai dengan data laporan yang ada di Puskesmas Pagesangan. WHO menjelaskan bahwa Demam Berdarah Dengue (DBD) merupakan salah satu penyakit menular yang dapat menimbulkan wabah. Berdasarkan data dari Puskesmas Pagesangan pada Tahun 2009 diperoleh data kejadian Demam Berdarah Dengue (DBD) di Lingkungan Pagesangan Timur mengalami peningkatan yang cukup signifikan setiap tahunnya. Berdasarkan data hasil penelitian yang telah dilakukan menunjukkan bahwa semakin tinggi tingkat pendidikan semakin tinggi tingkat pengetahuan seseorang sehingga perilaku, sikap dan tindakan dalam melakukan upaya pencegahan kekambuhan Demam Berdarah Dengue (DBD) semakin baik. Hal ini sependapat dengan pernyataan yang disampaikan oleh Notoadmodjo (2003) yang menjelaskan bahwa tingkat pendidikan yang rendah merupakan masalah yang besar bagi keluarga dalam melaksanakan tugas keluarga. Keluarga dengan tingkat pendidikan yang tinggi memungkikan seseorang untuk mampu menerima dan memahami berbagai informasi yang yang berkaitan dengan Demam Berdarah
Dengue (DBD). Berbagai indormasi yang telah dipahaminya tersebut diharapkan mampu untuk diterapkan dalam melakukan berbagai upaya yang telah ada dan diketahuinya untuk mencegah Demam Berdarah Dengue (DBD) dengan optimal. Hal ini sesuai dengan fakta yang terjadi di masyarakat khususnya warga yang bermukim di Lingkungan Pagesangan Timur menunjukkan bahwa keluarga yang memiliki pengetahuan yang baik memiliki kecenderungan untuk mencegah upaya untuk mencegah Demam Berdarah Dengue (DBD) dalam kategori baik.

\section{KESIMPULAN}

Berdasarkan analisa data dan pembahasan hasil penelitian, maka dapat ditarik kesimpulan sebagai berikut : 1) Upaya pencegahan secara optimal terutama dalam penggunaan obat anti nyamuk, menggunakan kawat kasa pada ventilasi atau lubang angin dan mengubur/memisahkan/membakar sampah yang dapat menampung air, serta tidak mampu menjaga kebersihan lingkungan dalam rumah; 2) Ada hubungan yang rendah antara kemampuan keluarga dalam mengenal masalah dengan upaya keluarga mencegah kekambuhan Demam Berdarah Dengue (DBD).

\section{DAFTAR PUSTAKA}

Ady. 2009. Kasus DBD Di Kota Mataram. http://www.Globalfmlombok.com/inde x. php?p=detilnews\&id news $=1098$

Alimul, A. 2002. Riset Keperawatan Dan Teknik Penulisan Ilmiah. Jakarta : Salemba Medika

Arikunto. 2002. Prosedur Penelitian Suatu Pendekatan Prkatik Edisi Revisi. Yogyakarta : Rineka Cipta

Depkes Gorontalo. 2009. Petunjuk Upaya Perawatan Pasien DBD". Gorontalo : http://dinkesbonebolango.org

Depkes. 2004. Demam Berdarah dan Pencegahannya.

http://www.depkes.go.id/downloads/tat a\%20laksana\%20DBD

Kandun, I.N. 2004. Suara Pembaharuan. http://www.suarapembaharuan.com/ne ws/2004/04/04/index.html

Maironah. 2005. Peran Ibu Dalam Pencegahan DBD. http://www.infoibu.com 
Terakreditasi Peringkat 5 (No. SK: 85/M/KPT/2020)

Mansjoer. 2000. Kapita Selekta Kedokteran Edisi $\mathrm{Ke}$-3. Jakarta : EGC

Marlina, S. 2008. Demam Berdarah Di Indonesia.

http://www.infeksi.com/articles.php?1i ng=In\&pg=53

Moloeng, Lexy J. 2007. Metodologi Penelitian Kualitatif. Bandung : Rosdakarya

Notoadmodjo. 2003. Pendidikan dan Perilaku Kesehatan. Jakarta: Asdi Maha Satya

Notoadmodjo. 2005. Metodologi Penelitian Kesehatan. Jakarta: Rineka Cipta

Suprajitno. 2004. Asuhan Keperawatan Keluarga. Bandung : Alfabeta

Wahyuni, C.H. 2008. Peran Faktor Lingkungan dan Perilaku Terhadap Penularan Demam Berdarah Dengue di Kota Mataram. http://www.Journal.UNAIR.ac.id/Filer PDF/Kesling-2-1-01.PDF

Widiastuty, P. 2005. Pencegahan dan Pengendalian Dengue Demam Berdarah. Jakarta: EGC

Yatim, F. 2001. Macam-macam Penyakit Menular dan Pencegahannya. Jakarta :Pustaka Populer Obor 